\title{
An updated inventory of the vascular flora of Elba island (Tuscan Archipelago, Italy)
}

\author{
Angelino Carta', Leonardo Forbicioni ${ }^{2}$, Giuliano Frangini ${ }^{3}$, \\ Brunello Pierini ${ }^{4}$, Lorenzo Peruzzi ${ }^{1}$
}

I Dipartimento di Biologia, Università di Pisa, Italy 2 Via Roma 6, 57037 Portoferraio (Livorno), Italy 3 Via Aldo Moro 7, 57037 Portoferraio (Livorno), Italy 4 Via Zamenhof 2, 56127 Pisa, Italy

Corresponding author: Lorenzo Peruzzi (lorenzo.peruzzi@unipi.it)

Academic editor: S. Bogdanovic | Received 11 May 2018 | Accepted 29 June 2018 | Published 5 July 2018

Citation: Carta A, Forbicioni L, Frangini G, Pierini B, Peruzzi L (2018) An updated inventory of the vascular flora of Elba island (Tuscan Archipelago, Italy). Italian Botanist 6: 1-22. https://doi.org/10.3897/italianbotanist.6.26568

\begin{abstract}
We present an updated list of the vascular flora occurring on Elba island (Tuscan Archipelago). The list is based on bibliographic analysis and field studies carried out in the years 2006-2018. With a total of 1,098 specific and subspecific taxa currently occurring on the island (including 101 naturalized aliens), plus 67 casual aliens and 16 hybrid taxa, Elba shows the highest number of species among the islands of the Tuscan Archipelago. Two taxa are new for Tuscany: Hieracium symphytaceum s.l. and Ophrys exaltata subsp. morisii; 22 taxa are new for the island, 34 have been confirmed, while 326 were reliably recorded previously by other authors, but not confirmed by our study. We excluded 41 taxa and considered doubtful the occurrence of 87. Life forms and chorotypes are in agreement with the Mediterranean climate of the island. Despite this, Elba also hosts a considerable proportion of Eurosiberian taxa. We detected significant differences in chorotypes and life forms spectra among different geographical portions of the island, paralleling distinct bioclimatic patterns. Despite the institution of the Tuscan Archipelago National Park, we are still far from an integrated protection of the island flora. Based on our results, it has been possible to arrange a geodatabase of the flora on the island, useful for its protection.
\end{abstract}

\section{Keywords}

alien species, biodiversity, endemics, floristic data, Italy, phytogeography, Tuscany

Copyright Angelino Carta et al. This is an open access article distributed under the terms of the Creative Commons Attribution License (CC BY 4.0), which permits unrestricted use, distribution, and reproduction in any medium, provided the original author and source are credited. 


\section{Introduction}

A flora is a useful source of information for biogeographical, ecological and evolutionary studies (Peruzzi 2018 and literature cited therein) and thus, floristic inventories and the analyses of plant species distribution across a geographic area are crucial to provide suitable data for decision-making processes in biodiversity conservation and landscape planning (Luque 2000, Heywood 2017, Thomson et al. 2018).

Particularly, islands have long served as an inspiration for evolutionary hypotheses because their biotic assemblages and ecological processes are clearly delimited by geographical constraints (MacArthur and Wilson 1967, Whittaker and FernandezPalacios 2013). Islands are indeed not simply miniature continents (Nunn 2004): they host peculiar and often unique and vulnerable floras.

The Mediterranean Basin is recognised among the most altered hotspots of biological diversity worldwide (Myers et al. 2000). Traditional, long established land use practices in the Mediterranean significantly contributed to the current biological and landscape features (Blondel 2006, Baiamonte et al. 2015). However, significant land use changes mainly associated with a switch from a traditional economy based on agriculture towards an industrial or tourism economy took place since the end of World War II (Vogiatzakis et al. 2008). The effects of land use changes on islands are often stronger than those observed on mainland areas (Delanoë et al. 1996).

The Tuscan Archipelago consists of seven islands and about twenty islets midway between mainland Italy and Corsica (France), and is one of the most interesting areas in the Central Mediterranean area from a naturalistic point of view (Arrigoni et al. 2003, Carta et al. 2013). Despite this, it has been strongly affected by socio-economic changes. All islands have been explored several times by botanists over the last centuries. Between the $19^{\text {th }}$ and $20^{\text {th }}$ centuries, the first comprehensive study on the Tuscan Archipelago flora was published (Sommier 1902, 1903): one of the first studies devoted to a group of small islands (Greuter 1995). With a total area of $220 \mathrm{~km}^{2}$, Elba is the largest of all islands forming the Tuscan Archipelago. The island reaches a maximum altitude of 1,019 $\mathrm{m}$ a.s.l. (Monte Capanne) and shows a high geomorphological variability, leading to the establishment of three distinct bioclimatic belts and a large vegetation diversity (Foggi et al. 2006). Since 1996, over half of the territory is included within the Tuscan Archipelago National Park. Nevertheless, during the last decades, the island experienced a socio-economic transition from an economy largely based on traditional agricultural exploitation to an economy based on tourism, which determined a substantial land use shift (Carta et al. 2018b). This land use shift was paralleled by significant floristic changes mostly due to an increase in the number of alien species (Chiarucci et al. 2017). Altogether, these conditions make Elba an interesting place to study plant assemblages and drawing up an updated floristic inventory.

Starting from the mid-1900s, several studies were devoted to the flora of the Elba island (Fossi Innamorati 1983 and literature cited therein), including two excursions of the Italian Botanical Society (Negri 1950, Signorini et al. 2002), and the completion of a floristic prodrome for the island (Fossi Innamorati 1983, 1989, 1991, 
1994, 1997), mainly based on a critical review of the collections made by S. Sommier. Thereafter, several floristic (Mannocci 2004, 2009, Bertacchi et al. 2005, Frangini et al. 2005, 2006, Borzatti de Loewenstern and Mannocci 2008, Foggi et al. 2015), vegetation (Foggi et al. 2006, Carta 2009), and taxonomic (Signorini and Foggi 1998, Peruzzi and Carta 2011, 2013, Ardenghi et al. 2014) studies were published. Also a recent list of names (Chiarucci et al. 2017) was published, however lacking a comprehensive analysis of previous literature and lacking a synthesis using an updated and coherent nomenclature. Hence, the aim of our study is to finalise an updated inventory of vascular flora on Elba island by tracking the current and past records of taxa, possibly identifying their distribution on the island, taking into account recent socio-economic changes that have significantly changed the landscape and the flora. In addition, to analyse more deeply plant distribution patterns, the island was subdivided into 12 bioclimatically homogeneous sectors in which we recorded plant occurrences and thereafter evaluated environmentally driven effects on species number, historical distribution, chorology and life form spectra.

\section{Material and methods}

\section{Floristic inventory}

We searched all published papers dealing with plants on Elba island and extracted occurrence records for all those species reported for the island. Smaller islets around Elba island were not considered because their flora was already studied and published by Foggi et al. (2009a). In addition to the papers cited in the Introduction, the following references were checked: Koestlin (1780), Thiébaut De Berneaud (1808), Caruel (1860, 1870), Bolzon (1893, 1894), Baroni (1897-1908), Fiori (1923-1929, 1943), Corti (1940), Marcello (1951), Ottens (1967), Arrigoni (1976, 2016, 2017), Jalas and Suominen (1976), Paoli and Romagnoli (1976), Zangheri (1976), Viegi and Cela Renzoni (1981), Pignatti (1982a-b), Nardi (1984), Natali (1988), Banfi (1989, 2017), Landi (1989), Gatteschi and Arretini (1990), Alessandro et al. (1991), Corsi and Garbari (1991), Baldini (1993), Del Prete and Tosi (1994), Bussotti et al. (1997), Hofmann et al. (1998), Rizzotto (1999), Vagge and Biondi (1999), Rinaldi (2000), Breiner and Breiner (2001, 2002), Del Prete (2001), Adamoli and Rigon (2003), Pignotti (2003), Ackermann and Ackermann (2004), Frangini (2004), Group of European Pteridologists (2004), Fanelli and Tescarollo (2005), Frangini et al. (2005, 2006), Tavormina (2006), Atzori (2007), Barsotti (2008), Bedini et al. (2008), Guiggi (2008, 2014), Hoffmann and Hoffmann (2008), Iamonico et al. (2008, 2011), Foggi and Venturi (2010), Arrigoni and Viegi (2011), Frignani and Iiriti (2011), Ferretti and Foggi (2013), Ferretti et al. (2013), Lazzaro et al. (2013a-b, 2014a-b), Ardenghi et al. (2014, 2015), Bagella et al. (2015), Cecchi and Selvi (2015), Iamonico (2015), Signorini and Tani (2015), Roma-Marzio et al. (2016, 2017), Scoppola et al. (2016), Benítez-Benítez et al. (2017), Martini and Viciani (2018), Troia et al. (2018). 
Besides the occurrence on the island, the collecting site was also recorded; localities reported on historical publications or herbarium labels were attributed to one or more of the identified operational geographic units (see below). Literature search was complemented by several field surveys carried out during the years 2006-2018 across the whole island; some sites (e.g., low altitude western slopes of Monte Capanne, Capoliveri mines) were visited multiple times during the same year, matching distinct flowering times across the seasons; other sites (e.g., Cala del Pisciatoio, Mola) were specifically visited to verify historical records or to explore under-sampled areas (as emerged from literature analyses). Our most relevant floristic findings were published during the research: Carta (2007, 2010a-b, 2011a-b, 2012, 2015), Carta et al. (2008, 2009, 2010a-b, 2011, 2012a-b, 2013), Carlesi and Peruzzi (2010), Carta and Frangini (2010, 2013), Frangini et al. (2010), Frangini and Carta (2011, 2012), Galasso et al. (2011, 2017), Iamonico and Forbicioni (2011), Forbicioni and Frangini (2012), Gonnelli et al. (2012), Pierini and Peruzzi (2012), Langeneck and Peruzzi (2013), Peruzzi et al. (2009, 2013, 2014, 2017), Forbicioni et al. (2014), Pierini (2014), Carta and Peruzzi (2015).

Nomenclature and circumscription of the taxa follow Bartolucci et al. (2018) and Galasso et al. (2018); angiosperm families are arranged according to APG IV (2016). According to the former authors, for coding the occurrence status of each taxon on Elba island, we refer to the following categories: Doubtfully occurring: "D"; No longer recorded (reliable historical record): "NC"; Recorded by mistake: "NP". Native (or putatively native) plants are in bold in the list; naturalized alien plants are not in bold, while casual aliens and/or cultivated taxa, but also NP taxa, are in italics. The new records for the island are marked as "New", while taxa confirmed for the island in this contribution are marked by the symbol "*". Life forms and chorotypes were attributed according to Pignatti (1982a). The complete dataset assembled for the present study is available in Suppl. material 1.

\section{Temporal, spatial and statistical analyses}

The OGUs were identified based on bioclimatic (see Foggi et al. 2006 for further details) and geographical features of the island. Each OGU is labelled by a combination of a number $(1,2,3)$ and a letter $(\mathrm{a}, \mathrm{b}, \mathrm{c}, \mathrm{d}, \mathrm{e})$. The numbers distinguish the western (1), central (2), and eastern (3) portion of the island, recalling a previous attempt (Arrigoni et al. 2003) to identify the western part of the island as more influenced by Western-Mediterranean Sardinian-Corsican taxa compared to the eastern one. The letters identify different ecological belts (Fig. 1). For analytical purposes, plant occurrences were assembled in two main periods (before 1950 and after 1950) and in twelve sectors (Operational Geographic Units, OGUs thereafter) (Fig. 1); species recorded in a given OGU before 1950 is indicated with an "s" ahead the label of the sector and considered as historical. We selected this temporal threshold because of the socioeconomic transition experienced by the island after the 1950s. 


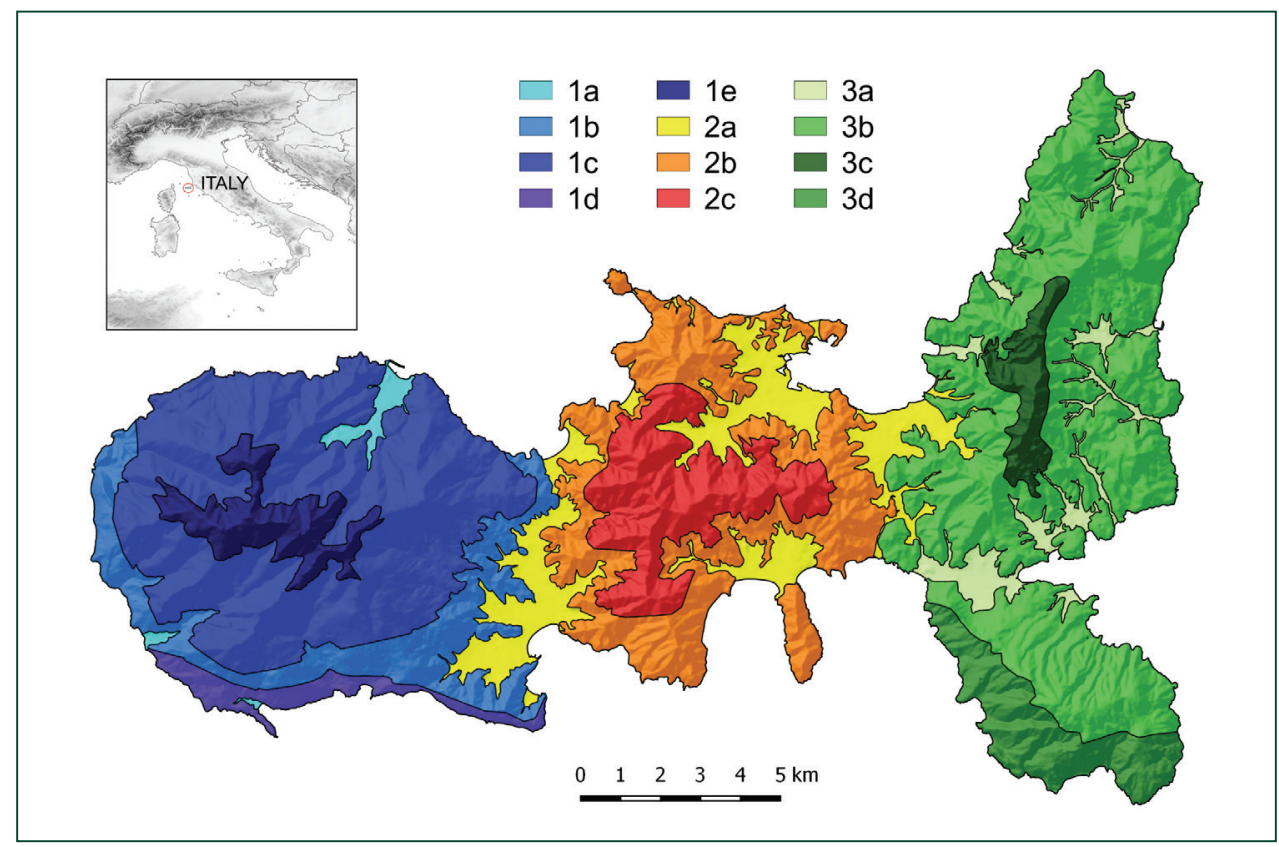

Figure I. Localisaton of Elba island (red circle) in the Central Mediterranean area and subdivision of the island into 12 Operational Geographic Units. The numbers distinguish the western (I), central (2), and eastern (3) portion of the island, while the letters distinguish ecological belts as follows: (a) alluvial plains, stream banks and shores, (b) hilly areas below $250 \mathrm{~m}$ a.s.l., mostly characterised by a mesomediterranean thermotype and a subhumid ombrotype, (c) hilly and mountain areas generally above 250 and below 700 $\mathrm{m}$ a.s.l. characterised by mesomediterranean thermotype and humid ombrotype, (d) coastal hilly areas with a thermomediterranean thermotype, and (e) mountain areas above $700 \mathrm{~m}$ a.s.l. characterised by mesomediterranean and supramediterranean thermotypes.

To assess whether observed frequencies of categorical variables (historical occurrence, taxonomic rank, chorology, and life form) differ significantly from theoretical expectations, we used $\chi^{2}$ tests. In addition, to determine whether there was a significant association between two categorical variables (among those listed above), we also applied a $\chi^{2}$ test of independence or simple multinomial logit model (for binary categories, namely confirmation). All analyses were performed with the software R (R Development Core Team 2017).

\section{Results}

\section{Floristic inventory}

A total of 1,098 specific and subspecific taxa currently occur on the island, including 101 naturalized aliens, representing about $9 \%$ of the flora, not considering casual aliens 
(67) and hybrid taxa (16); Hieracium symphytaceum Arv.-Touv. s.l. and Ophrys exaltata Ten. subsp. morisii (Martelli) Del Prete are new records for Tuscany, and 22 taxa are new for the island (including 3 naturalized and 5 casuals aliens); among them, Galium verrucosum Huds. subsp. halophilum (Ponzo) Lambinon and Verbascum conocarpum Moris subsp. conocarpum are of particular relevance. While 34 taxa have been directly confirmed during field surveys (e.g., Bellevalia romana (L.) Sweet, Cerinthe major L. subsp. major, Lamium purpureum L.), 326 taxa reliably recorded in the past were not confirmed (e.g., Asplenium sagittatum (DC.) Bange, Thelypteris palustris Schott, Nymphaea alba L., Sagittaria sagittifolia L., Hypecoum procumbens L. subsp. procumbens, Lotus conimbricensis Brot.). We excluded 41 taxa (e.g., Oxalis acetosella L., Romulea insularis Sommier, Rosa rubiginosa L.), and considered doubtful the occurrence of 87 taxa (e.g., Allium parciflorum Viv., Briza media L., Polygala flavescens DC. subsp. Alavescens, Soleirolia soleirolii (Req.) Dandy). Overall, neither our direct field effort nor field researches conducted around the 1950 temporal threshold (Negri 1950, Marcello 1951) had a significant effect on current floristic diversity ( $p>0.05)$.

Concerning the distribution of floristic diversity, while for 12 taxa a detailed distribution on the island is not available, 3b, 1c, and 2a show, respectively, 589, 546 and 540 taxa, and are the OGUs hosting the highest number of taxa. Floristic diversity is largely comparable among western (1), central (2) and eastern (3) portions of the island, but shows significant differences $(\mathrm{p}<0.001)$ among ecological belts, with (d) and (e) being the poorest ecological belts, while (c), and especially (b), are the richest.

Considering the whole island, three families alone cover more than $30 \%$ of the total vascular flora (Asteraceae 124, Fabaceae 116, and Poaceae 112). However, an analysis by OGUs revealed that Fabaceae is the most represented family, showing in all sectors slightly more taxa than Asteraceae. The most represented genera are Trifolium (35), Vicia, and Carex (20).

Biological and chorological spectra highlight that therophytes (39\%), hemicryptophytes (27\%), and geophytes (15\%) are the most represented life forms, while Mediterranean (47\%), Euro-Mediterranean (24\%), and Eurosiberian (11\%) are the most frequent chorotypes. Alien taxa represent $6 \%$ of the total flora.

Italian endemics (Peruzzi et al. 2014, 2015, Bartolucci et al. 2018) are 26: 11 taxa show wide Italian distribution: Biscutella maritima Ten., Carex microcarpa Bertol. ex Moris, Crocus biflorus Mill., Genista desoleana Vals., Helichrysum litoreum Guss., Ophrys appennina Romolini \& Soca, O. classica Devillers-Tersch. \& Devillers, O. crabronifera Mauri, O. exaltata Ten. subsp. montis-leonis (O.Danesch. \& E.Danesch) Soca, O. tenthredinifera Willd. subsp. neglecta (Parl.) E.G.Camus, and Ornithogalum etruscum Parl. subsp. etruscum; 6 taxa are Sardinian-Corsican-Tuscan Archipelago endemics: Hypericum hircinum L. subsp. hircinum, Ophrys exaltata subsp. morisii, Pancratium illyricum L., Sagina revelierei Jord. \& Fourr., Stachys salisii Jord. \& Fourr, and Verbascum conocarpum subsp. conocarpum. Just 1 taxon is endemic to Tuscan Archipelago (Linaria capraria Moris \& De Not.), while 8 taxa are narrow endemic to Elba: Biscutella pichiana Raffaelli subsp. ilvensis Raffaelli, Centaurea aetaliae (Sommier) Bég., C. ilvensis (Sommier) Arrigoni, Crocus ilvensis Peruzzi \& Carta, Festuca gamisansii Kerguélen 
subsp. aethaliae Signorini \& Foggi, Hieracium elbanum Belli ex Baroni, Limonium ilvae Pignatti, and Viola corsica Nyman subsp. ilvensis (W.Becker) Merxm.

Further 19 taxa occurring on the island are of high phytogeographical interest: Cymbalaria aequitriloba (Viv.) A.Chev. subsp. aequitriloba, Dorycnopsis gerardii (L.) Boiss., Dryopteris tyrrhena Fraser-Jenk. \& Reichst., Eudianthe laeta Rchb. ex Willk., Gagea granatellii (Parl.) Parl., Fumana scoparia Pomel, Isoëtes gymnocarpa (Gennari) A.Braun, Mesembryanthemum nodiflorum L., and Urtica atrovirens (Req.) Loisel. are at the margin of their distribution range on Elba Island, while Carex paui Sennen, Cosentinia vellea (Aiton) Tod. subsp. vellea, Gennaria diphylla (Link) Parl., Juncus ranarius Songeon \& E.P.Perrier, Oeosporangium pteridioides (Reichard) Franser-Jenk. \& Pariyar, Phalaris elongata Braun-Blanq., Poa perligularis H.Scholz, Sedum brevifolium DC., Stachys marrubiifolia Viv., and Thymbra capitata (L.) Cav. can be found in Tuscany only on Elba Island (Peruzzi and Bedini 2015 onwards).

\section{Temporal and spatial analyses}

Taxa confirmations are not equally distributed among life forms, chorotypes, and OGUs (Figs 2, 3). Not confirmed taxa are significantly more abundant (significance level $\mathrm{p}<0.001)$ among therophytes and especially hydrophytes, but also $(\mathrm{p}<0.001)$ within the Eurosiberian chorotype. The portion of the island with less confirmed taxa is the sector 2, especially within belt (b). Whilst taxa confirmations resulted equally distributed ( $p>0.05$ ) among families, Apiaceae, Boraginaceae, Caprifoliaceae, and Fabaceae show respectively 37\%, 20\%, 30\% e 25\% of not recently confirmed taxa.

Families are mostly equally distributed $(\mathrm{p}>0.05)$ among sectors and belts. Life forms and chorotypes are however not equally distributed $(p<0.001)$ among families. Lamiaceae and Plantaginaceae well represent chamaephytes (12\% each, after excluding the three richest families), Orchidaceae and Amaryllidaceae prevail among geophytes (26\% and $11 \%$ respectively), Alismataceae dominate the hydrophytes (21\%), and Rosaceae dominate the nanophanerophytes (26\%). Taxa showing wide (cosmopolitan/ subcosmopolitan) distribution prevail in Poaceae, while Fabaceae are especially common among Mediterranean taxa (16\%), and Asteraceae prevail within the Eurosiberian chorotype (11\%).

Life forms are significantly associated $(\mathrm{p}<0.001)$ with chorotypes: Mediterranean taxa are mostly represented by therophytes (46\%), and Eurosiberian taxa are mostly represented by hemicryptophytes (40\%). Italian endemics are mostly hemicryptophytes $(39 \%)$ and geophytes $(34 \%)$, while alien taxa are mostly represented by phanerophytes and therophytes (more than 60\% altogether).

Life forms are also significantly associated ( $\mathrm{p}<0.001$ ) with OGUs (Fig. 2), particularly: chamaephytes are especially frequent $(37 \%)$ on belt (b) and hydrophytes on belt (a) (71\%); therophytes are underrepresented in 1e (around 35\%; exceeding 40\% in all other OGUs), and hemicryptophytes dominate 1e and the OGUs of belt (c). 


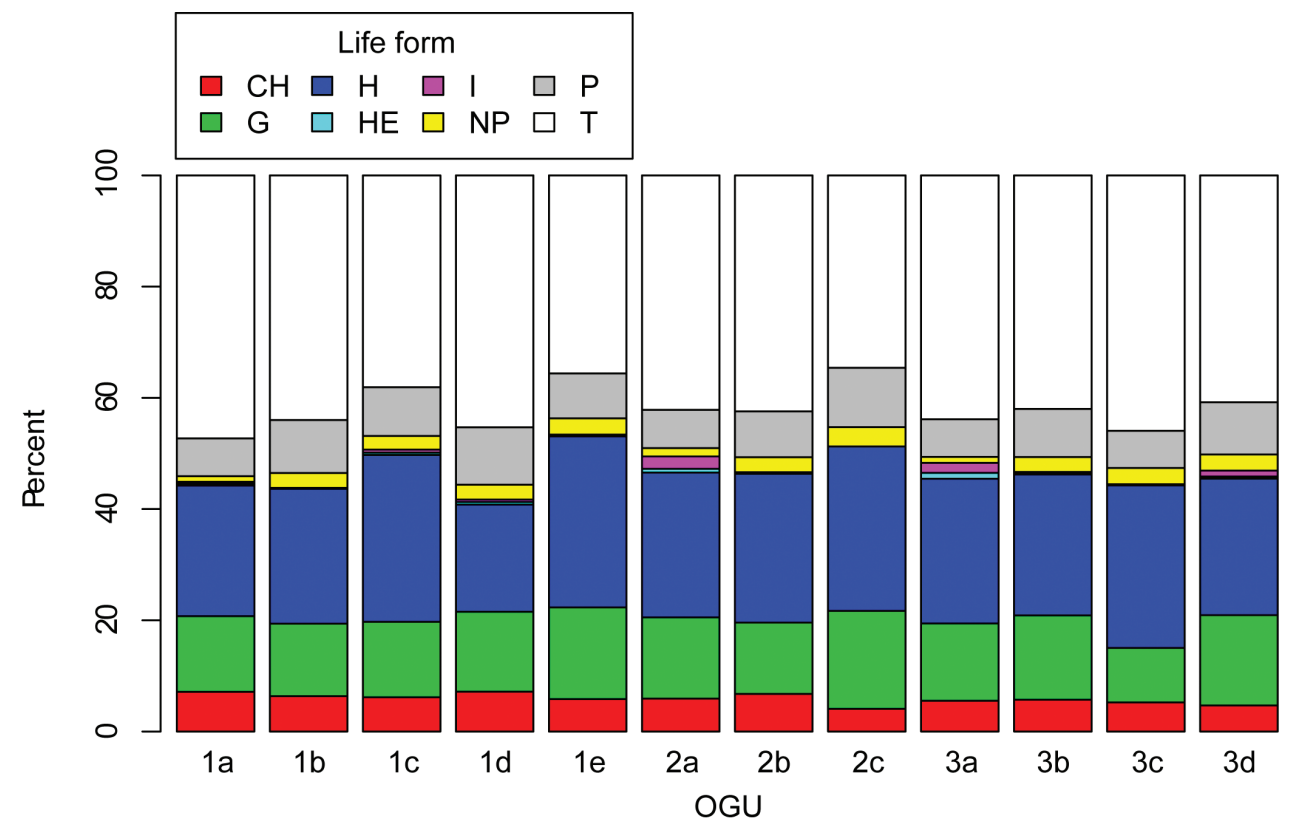

Figure 2. Life form spectra for each Operational Geographic Unit. $\mathrm{CH}=$ Chamaephytes, $\mathrm{G}=$ Geophytes, $\mathrm{H}=$ Hemicryptophytes, $\mathrm{HE}=$ Helophytes, $\mathrm{I}=$ Idrophytes, $\mathrm{NP}=$ Nanophanerophytes, $\mathrm{P}=$ Phanerophytes, $\mathrm{T}=$ Therophytes.

Chorotypes are also significantly associated ( $\mathrm{p}<0.001)$ with the OGUs (Fig. 3), with 1e particularly characterised by Italian endemics (5.5\%), while the warmest and most urbanised OGUs (1a, 1d, 2a, 2b, 3a, 3b, and 3d) are associated with the occurrence of aliens. Finally, Eurosiberian taxa are underrepresented (less than 2\%) in the warmest OGUs (1d and 3d).

\section{Discussion}

With a total of 1,098 specific and subspecific taxa currently occurring on the island, Elba is confirmed as the island hosting the highest number of vascular taxa in the Tuscan Archipelago. This is mostly due to the larger extension of Elba compared to other islands (Chiarucci et al. 2017), but also to a larger geological and bioclimatic variability leading to higher habitat and niche diversity (Foggi et al. 2006, Carta et al. 2013). However, further analyses based on species-area relationship are required to disentangle the main ecological factors driving plant richness (D'Antraccoli et al. 2017), and possibly plant diversity (Carta et al. 2018a), on Elba island. In order to ascertain whether Elba can considered as a vascular plant diversity centre (see Carta et al. 2018a for pteridophytes), the data published here should be analysed by means of phylogenetic comparative methods. 


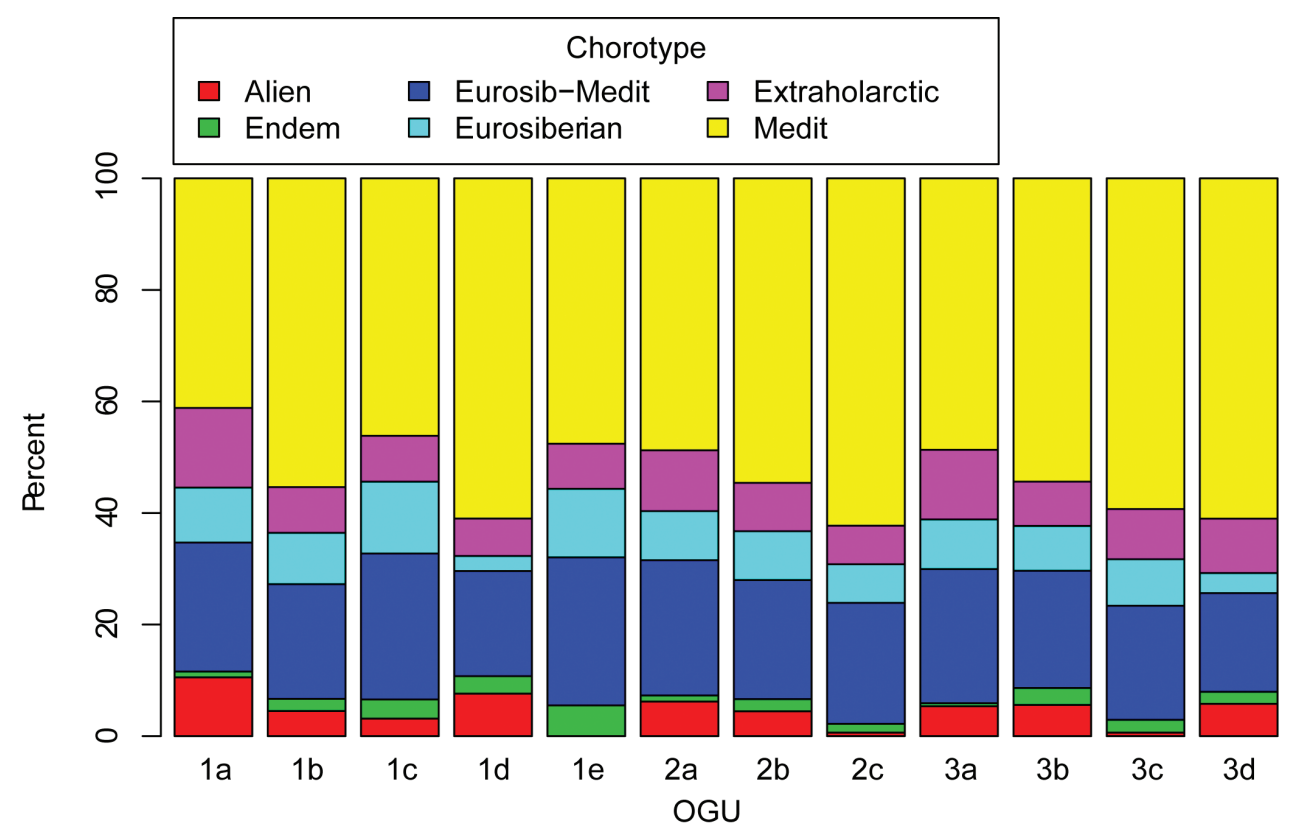

Figure 3. Chorological spectra for each Operational Geographic Unit. Alien = alien species, Endem = Italian endemic species, Extraholarctic = species showing range larger than Holarctic floristic kingdom, Eurosiberian $=$ species showing range within the Eurosiberian floristic region, Eurosib-Medit $=$ species showing range across Eurosiberian and Mediterranean floristic regions, Medit = species showing range within the Mediterranean floristic region.

The overall analysis of life forms and chorotypes revealed that the major component of the flora reflects the Mediterranean setting of the island and the prevalence of anthropogenic, secondary forms of vegetation (Arrigoni et al. 2003), belonging to the evergreen oak series (Foggi et al. 2006). Indeed, the most frequent life forms include herbs that especially grow in open, sunny habitats derived from the degradation of woodlands. Human influence has been massive since Roman times, but the vegetation has recently evolved towards more structured communities after the decrease of mining and agricultural activity (Carta et al. 2018b), possibly leading to a reduction of annual species (Chiarucci et al. 2017). However, it should be highlighted that 33 taxa considered as extinct or not recently confirmed by other authors (Fossi Innamorati 1997, Bertacchi et al. 2005, Chiarucci et al. 2017) have been eventually confirmed in our study. Nevertheless, our analysis highlights that the overall species confirmation is not depending from a single research group, but from several researchers separately active and in different times (especially after the world war II).

Elba hosts around $80 \%$ of the flora of the entire Tuscan Archipelago (Arrigoni et al. 2003, Carta et al. 2013), making any attempt to compare floras among Archipelago islands rather superfluous. However, besides being characterised by typical Mediterranean features, the flora of Elba also hosts a considerable proportion of Eurosiberian 
taxa, largely not occurring on other islands. On the contrary, the flora of temporary wet habitats (Carta 2009) is also well represented in other islands of the Archipelago, especially in Capraia (Foggi et al. 2009). Shrubs and nanophanerophytes (Lamiaceae, Plantaginaceae, and Rosaceae) are linked with mesophilous habitats and are more common on Elba than in other islands. The ruderal flora associated with cultivated lands, and often represented by several crop wild relatives, is well represented on the island. However, we were not able to quantify it and further analyses are required to assess the influence of current agricultural activities on the survival of the species belonging to this peculiar flora and to make comparisons with other islands (especially Pianosa, for its long standing cultivations, see Baldini 2000).

The problem of alien species has already been highlighted by Chiarucci et al. (2017), and the number of aliens after our study is even higher than previously reported (84 naturalized and 45 casual aliens in Chiarucci et al. 2017, 101 naturalized and 67 casual aliens in our study). The total flora also including casual aliens lists 1,166 taxa, while Chiarucci et al. (2017) listed 1,013 and Fossi Innamorati (1997) 1,396 taxa. Nevertheless, Chiarucci et al. (2017) also include several species considered here as doubtful and especially lack a coherent nomenclature, while Fossi Innamorati (1997) include in the published number doubtful, not confirmed and even reportedby-mistake taxa. When all these categories are also included, our inventory exceeds 1,500 taxa, so that we conclude that these differences with previous published floras are illusory, or mostly linked to the recent acquisition of alien taxa.

The OGUs hosting the higher number of species (3b, 1c, 2a) are also the largest ones (Fig. 1). Nevertheless, we showed that plant species are non evenly distributed on the island, and the analyses suggest that the main factor influencing plant distribution is indeed local climate. A turnover analysis (Legendre 2014) would be needed to clearly demonstrate plant distribution variation among OGUs, but we detected significant differences in chorotypes and life forms spectra among OGUs, reflecting an altitudinal/bioclimatic trend (especially $1 \mathrm{~b}>1 \mathrm{c}>1 \mathrm{e}$ ). Furthermore, sectors 1d, 1e, 2a, and 3a host a peculiar flora compared to other sectors for climatic and edaphic reason. While $1 \mathrm{~d}$ is particularly rich in xeric taxa, sectors $2 \mathrm{a}$ and 3 a host the largest number of aquatic or wetland plants, even if in these alluvial sectors the fresh and brackish water habitats have been strongly reduced from past decades (Carta et al. 2018b).

OGU 1e, besides hosting a flora with temperate features, also hosts the majority of Italian endemics, albeit a few endemics are however also occurring in coastal habitats (Limonium ilvae) or in rocky cliffs spread across the island (Linaria capraria). Although it is difficult to reconstruct the geological events that possibly provided past links between Elba and other territories, some endemics show clear taxonomic relationships with the Sardinian-Corsican flora (Signorini and Foggi 1998, Borzatti de Loewenstern and Mannocci 2009, Carta and Peruzzi 2015) while others show a clear relationship with the Italian peninsula (Arrigoni 2003, Peruzzi and Carta 2011). Furthermore, several authors (Arrigoni 1976, Arrigoni et al. 2003, Carta et al. 2013, Foggi et al. 2015) repeatedly reported a higher western-Mediterranean (and especially Sardinian-Corsican) phytogeographical affinity for the western portion of the island 
compared with the eastern one. Despite this, we did not detect significant differences in the major chorotype proportions between these two geographical sectors.

\section{Conclusions}

In spite of the institution of the Tuscan Archipelago National Park, including several specific in situ and ex situ conservation activities (Carta et al. 2012c, Foggi et al. 2015), we are still far from an integrated protection of the island flora. Based on our results, it has been possible to arrange an updated geodatabase of the flora on the island useful for its protection (Peruzzi and Bedini 2015 onwards). To this end, however, a landscape management plan avoiding land-use polarization through tourism, especially along the coast, promoting instead traditional use of woodland and agricultural activities should be promoted. Challenges remain at the policy level, particularly the decision making process and the opportunity to better define the role of science and protected areas in plant diversity conservation.

\section{Acknowledgements}

We are grateful to friends of Acta Plantarum, Roberto Adamoli, Fabrizio Bartolucci, Mario Calbi, Leonardo Cocchi, Marco D’Antraccoli, Gloria Cortesi, Giovanni Gestri, Gianniantonio Domina, Michele and Rolando Galeazzi, Valerio Lazzeri, Mairo Mannocci, Dino Marchetti, Francesco Roma-Marzio, and Adriano Soldano for helping in the identification of some taxa and for providing useful information on localities and/or literature. Finally, Gianniantonio Domina and Gabriele Galasso are gratefully acknowledged for their careful reviews and useful suggestions.

\section{References}

Ackermann M, Ackermann M (2004) Orchideenfunde auf der Insel Elba. Journal of Europäischer Orchideen 36(3): 691-734.

Adamoli R, Rigon D (2003) Natura Mediterranea Flora elbana di Lacona. Documentazione Salute Ambiente Lacona-Capoliveri, Isola d'Elba.

Alessandro V, Bagnoli M, Bargelli S, Di Gregorio A, Giordano A, Ongaro L, Puglisi C, Rodolfi G, Sarfatti P, Ambrosini I, Angelini S, Brandolini G, Dell'Agnello A, De Luca M, Fais I, Galzerano CM, Giudiceandrea AMP, Mahdaoui M, Palavicino J, Peirano M, Rosati I, Salvucci R, Sericola A, Timchebeche ML (1991) Carta delle Unità di Terre dell'isola d'Elba. Ministero degli Affari Esteri, Istituto di Agronomia Oltremare, Firenze.

APG IV (2016) An update of the Angiosperm Phylogeny Group classification for the orders and families of flowering plants: APG IV. Botanical Journal of the Linnean Society 181(1): 1-20. https://doi.org/10.1111/boj.12385 
Ardenghi NMG, Banfi E, Galasso G (2015) A taxonomic survey of the genus Vitis L. (Vitaceae) in Italy, part II: the "EuroAmerican" hybrids. Phytotaxa 224(3): 232-246. https://doi. org/10.11646/phytotaxa.224.3.2

Ardenghi NMG, Galasso G, Banfi E, Zoccola A, Foggi B, Lastrucci L (2014) A taxonomic survey of the genus Vitis L. (Vitaceae) in Italy, with special reference to Elba Island (Tuscan Archipelago). Phytotaxa 166(3): 163-198. https://doi.org/10.11646/phytotaxa.166.3.1

Arrigoni PV (1976) Rapporti floristici tra l'Arcipelago Toscano e le terre vicine. Biogeographia, nuova serie 5(1974): 1-11. https://doi.org/10.21426/B65110064

Arrigoni PV (2003) Le Centauree italiane del gruppo Centaurea paniculata L. Parlatorea 6: 49-78.

Arrigoni PV (2016) Flora analitica della Toscana, Vol. 1. Edizioni Polistampa, Firenze.

Arrigoni PV (2017) Flora analitica della Toscana, Vol. 2. Edizioni Polistampa, Firenze.

Arrigoni PV, Baldini RM, Foggi B, Signorini MA (2003) Analysis of the floristic diversity of the Tuscan Archipelago for conservation purposes. Bocconea 16(1): 245-259.

Arrigoni PV, Viegi L (2011) La flora vascolare esotica spontaneizzata della Toscana. Regione Toscana, Firenze, 216 pp.

Atzori S (2007) Una popolazione di Cosentinia vellea (Aiton) Tod. (Hemionitidaceae, Pteridophyta) nell'Isola d'Elba. Annali del Museo Civivo di Rovereto, Sezione Architettura, Storia, Scienze Naturali 22(2006): 195-199.

Bagella S, Peruzzi L, Caria MC, Filigheddu R (2015) Unraveling the taxonomy and nomenclature Isoetes histrix Bory species complex (Isoetaceae, Lycopodiidae). Turkish Journal of Botany 39(2): 383-387. https://doi.org/10.3906/bot-1404-121

Baiamonte G, Domina G, Raimondo FM, Bazan G (2015) Agricultural landscapes and biodiversity conservation: a case study in Sicily (Italy). Biodiversity and Conservation 24: 3201-3216. https://doi.org/10.1007/s10531-015-0950-4

Baldini RM (1993) The genus Phalaris L. (Gramineae) in Italy. Webbia 47(1): 1-53. https:// doi.org/10.1080/00837792.1993.10670531

Baldini RM (2000) Flora vascolare dell'Isola di Pianosa (Arcipelago Toscano): revisione tassonomica ed aggiornamento. Webbia 55(1): 107-189. https://doi.org/10.1080/00837792. 2000.10670691

Banfi E (1989) Osservazioni sulle specie italiane del genere Setaria P.Beauv. (Poaceae). Atti della Società Italiana di Scienze Naturali, Museo Civico di Storia Naturale di Milano 130(13): 189-196.

Banfi E (2017) Poaceae. In: Pignatti S (Ed.) Flora d'Italia 1. Edagricole, New Business Media, Milano, 512-780.

Baroni E (1897-1908) Supplemento generale al Prodromo della Flora Toscana di T. Caruel. Società Botanica Italiana, Firenze.

Barsotti G (2008) Flora, vegetazione ed ambiente delle isole dell'Arcipelago toscano. Pacini Editore, Pisa.

Bartolucci F, Peruzzi L, Galasso G, Albano A, Alessandrini A, Ardenghi NMG, Astuti G, Bacchetta G, Ballelli S, Banfi E, Barberis G, Bernardo L, Bouvet D, Bovio M, Cecchi L, Di Pietro R, Domina G, Fascetti S, Fenu G, Festi F, Foggi B, Gallo L, Iamonico D, Iberite M, Jiménez-Mejías P, Lattanzi E, Marchetti D, Martinetto E, Masin RR, Medagli P, Passalac- 
qua NG, Peccenini S, Pennesi R, Pierini B, Poldini L, Prosser F, Raimondo FM, RomaMarzio F, Rosati L, Santangelo A, Scoppola A, Scortegagna S, Selvaggi A, Selvi F, Soldano A, Stinca A, Wagensommer RP, Wilhalm T, Conti F (2018) An updated checklist of the vascular flora native Italy. Plant Biosystems 152(2): 179-303. https://doi.org/10.1080/11 263504.2017.1419996

Bedini G, Giannelli L, Barzanti L, Bisti M, Frangini G, Filippi L (2008) Orchidaceae: nuove segnalazioni per l'Etruria marittima e l'isola d'Elba. GIROS Notizie 37: 29-36.

Benítez-Benítez C, Míguez M, Jiménez-Mejías P, Martín-Bravo S (2017) Molecular and morphological data resurrect the long neglected Carex laxula (Cyperaceae) and expand its range in the western Mediterranean. Anales del Jardín Botánico de Madrid 74(1): e057. https:// doi.org/10.3989/ajbm.2438

Bertacchi A, Kugler PC, Lombardi T, Mannocci M, Monaldi M, Spinelli P, Tomei PE (2005) Appendice al Prodromo della flora vascolare della provincia di Livorno. Edizioni ETS, Pisa, 156 pp.

Blondel J (2006) The "design" of Mediterranean landscapes: a millennial story of humans and ecological systems during the historic period. Human Ecology 34: 713-729. https://doi. org/10.1007/s10745-006-9030-4

Bolzon P (1893) Erborizzazione all'isola dell'Elba. Bollettino della Società Botanica Italiana 1893: 23-31, 166-173, 237-243, 306-313, 350-357, 411-418.

Bolzon P (1894) La Flora del territorio di Carrara. Bollettino della Società Botanica Italiana 1894: 104-112.

Borzatti de Loewenstern A, Mannocci M (2009) Stachys salisii Jord. \& Fourr. (Lamiaceae), endemismo sardo-corso nuovo per l'Arcipelago Toscano. Quaderni del Museo di Storia Naturale di Livorno 21(2008): 1-9.

Breiner E, Breiner R (2001) Orchideen der Insel Elba. Berichte aus den Arbeitskreisen Heimische Orchideen 18(2): 171-175.

Breiner E, Breiner R (2002) Orchideen der Insel Elba - Fundortverzeichnis. Berichte aus den Arbeitskreisen Heimische Orchideen 19(1): 82-84.

Bussotti L, Garbari F, Nannoni R (1997) Le stazioni di Chamaerops humilis L. (Arecaceae) nell'Arcipelago Toscano. Atti della Società Toscana di Scienze Naturali, Memorie, Serie B 103(1996): 115-118.

Carlesi V, Peruzzi L (2010) Notulae alla checklist della Flora vascolare italiana, 9: 1663. Informatore Botanico Italiano 42(1): 379.

Carta A (2007) Indagini fitosociologiche nel comune di Campo nell'Elba (Livorno). M.Sc. Thesis in Management and Estimation of Natural Resources, University of Pisa, A.A. 2006-2007.

Carta A (2009) Contributo alla conoscenza della classe Isoëto-Nanojuncetea dell'Isola d'Elba (Arcipelago Toscano - Livorno). Atti della Società Toscana di Scienze Naturali, Memorie, Serie B 115(2008): 35-42.

Carta A (2010a) Notulae alla checklist della Flora vascolare Italiana, 10: 1712. Informatore Botanico Italiano 42(2): 519.

Carta A (2010b) Segnalazioni 1-14. In: Peruzzi L, Viciani D, Bedini G (Eds) Contributi per una flora vascolare di Toscana. I. (1-85). Atti della Società Toscana di Scienze Naturali, Memorie, Serie B 116(2009): 33-44. 
Carta A (2011a) Notulae alla checklist della Flora vascolare Italiana, 12: 1848. Informatore Botanico Italiano 43(2): 361.

Carta A (2011b) Segnalazioni 95-102. In: Peruzzi L, Viciani D, Bedini G (Eds) Contributi per una flora vascolare di Toscana. II. (86-142). Atti della Società Toscana di Scienze Naturali, Memorie, Serie B 117(2010): 23-31.

Carta A (2015) Segnalazioni 345-346. In: Peruzzi L, Viciani D, Bedini G (Eds) Contributi per una flora vascolare di Toscana. VI. (320-356). Atti della Società Toscana di Scienze Naturali, Memorie, Serie B 121(2014): 29-35.

Carta A, Bedini G, Foggi B, Probert RJ (2012c) Laboratory germination and seed bank storage of Ranunculus peltatus subsp. baudotii seeds from the Tuscan Archipelago. Seed Science and Technology 40(1): 11-20. https://doi.org/10.15258/sst.2012.40.1.02

Carta A, Bedini G, Guidi T, Foggi B (2013) Tuscan Archipelago flora: from genesis to conservation. $2^{\text {nd }}$ Botanical Conference in Menorca. Proceedings and abstracts. Islands and plants: preservation and understanding of flora on Mediterranean Islands, 157-176.

Carta A, Frangini G (2010) Segnalazioni 24-26. In: Peruzzi L, Viciani D, Bedini G (Eds) Contributi per una flora vascolare di Toscana. I. (1-85). Atti della Società Toscana di Scienze Naturali, Memorie, Serie B 116(2009): 33-44.

Carta A, Frangini G (2013) Segnalazione 216. In: Peruzzi L, Viciani D, Bedini G (Eds) Contributi per una flora vascolare di Toscana. IV (181-246). Atti della Società Toscana di Scienze Naturali, Memorie, Serie B 119(2012): 23-32.

Carta A, Frangini G, Gestri G, Lazzeri V, Pierini B, Peruzzi L (2012a) Segnalazione 158. In: Peruzzi L, Viciani D, Bedini G (Eds) Contributi per una flora vascolare di Toscana. III. (143180). Atti della Società Toscana di Scienze Naturali, Memorie, Serie B 118(2011): 39-46.

Carta A, Gestri G, Mannocci M, Pierini B, Peruzzi L (2010a) Segnalazione 27. In: Peruzzi L, Viciani D, Bedini G (Eds) Contributi per una flora vascolare di Toscana. I. (1-85). Atti della Società Toscana di Scienze Naturali, Memorie, Serie B 116(2009): 36.

Carta A, Gestri G, Peruzzi L (2010b) Segnalazioni 15-18. In: Peruzzi L, Viciani D, Bedini G (Eds) Contributi per una flora vascolare di Toscana. I. (1-85). Atti della Società Toscana di Scienze Naturali, Memorie, Serie B 116(2009): 33-44.

Carta A, Limoncelli M, Peruzzi L (2013) Segnalazione 195. In: Peruzzi L, Viciani D, Bedini G (Eds) Contributi per una flora vascolare di Toscana. IV (181-246). Atti della Società Toscana di Scienze Naturali, Memorie, Serie B 119(2012): 23-32.

Carta A, Peruzzi L (2015) Contributo alla conoscenza della flora vascolare endemica di Toscana ed aree contermini. 6. Hypericum hircinum subsp. hircinum (Hypericaceae). Informatore Botanico Italiano 47(1): 27-31.

Carta A, Pierini B, Peruzzi L (2008) Distribuzione di Ophioglossum lusitanicum L. (Psilotopsida) in Toscana. Informatore Botanico Italiano 40(2): 135-141.

Carta A, Pierini B, Peruzzi L (2009) Aggiornamenti e novità sulla distribuzione di Isoëtes gymnocarpa e I. histrix (Lycopodiophytina) in Toscana. Atti della Società Toscana di Scienze Naturali, Memorie, Serie B 115(2008): 43-45.

Carta A, Pierini B, Peruzzi L (2011) Segnalazione 86. In: Peruzzi L, Viciani D, Bedini G (Eds) Contributi per una flora vascolare di Toscana. II. (86-142). Atti della Società Toscana di Scienze Naturali, Memorie, Serie B 117(2010): 23-31. 
Carta A, Pierini B, Peruzzi L (2012b) Segnalazione 178. In: Peruzzi L, Viciani D, Bedini G (Eds) Contributi per una flora vascolare di Toscana. III. (143-180). Atti della Società Toscana di Scienze Naturali, Memorie, Serie B 118(2011): 39-46.

Carta A, Pierini B, Roma-Marzio F, Bedini G, Peruzzi L (2018a) Phylogenetic measures of biodiversity uncover pteridophyte centres of diversity and hotspots in Tuscany. Plant Biosystems 152(4): 831-839. https://doi.org/10.1080/11263504.2017.1353550

Carta A, Taboada T, Müller JV (2018) Diachronic analysis using aerial photographs across fifty years reveals significant land use and vegetation changes on a Mediterranean island. Applied Geography: in press.

Caruel T (1860) Prodromo della Flora Toscana. Firenze.

Caruel T (1870) Secondo supplemento al Prodromo della Flora Toscana di T. Caruel. Firenze.

Cecchi L, Selvi F (2015) Synopsis of Boraginaceae subfam. Boraginoideae tribe Boragineae in Italy. Plant Biosystems 149(4): 630-677. https://doi.org/10.1080/11263504.2015.1057261

Chiarucci A, Fattorini S, Foggi B, Landi S, Lazzaro L, Podani J, Simberloff D (2017) Plant recording across two centuries reveals dramatic changes in species diversity of a Mediterranean archipelago. Scientific Reports 7(1): 5415. https://doi.org/10.1038/s41598-017-05114-5

Corsi G, Garbari F (1991) Elba, isola d'erba. Quaderni di S. Caterina. Eremo di S. Caterina, Rio nell'Elba. Ed. Pacini, Pisa.

Corti R (1940) Appunti sulla vegetazione dell'Isola d'Elba. I. Una gita a M. Orello e ai monti tra Rio Alto e Portolongone, con osservazioni sui distretti ofiolitici dell'Isola. Nuovo Giornale Botanico Italiano, nuova serie 47: 494-504.

D’Antraccoli M, Roma-Marzio F, Carta A, Landi S, Bedini G, Chiarucci A, Peruzzi L (2017) L'uso delle relazioni specie-area come strumento per confrontare flore. Notiziario della Società Botanica Italiana 1(2): 178-179.

Delanoë O, Montmollin de B, Olivier L (1996) Conservation of Mediterranean island Plants. I. Strategy for Action. I.U.C.N./S.S.C. Mediterranean Islands Plant Specialist Group.

Del Prete C (2001) Le orchidee spontanee. Elba, territorio e civiltà di un'isola. RS editore, Genova.

Del Prete C, Tosi G (1994) Le orchidee spontanee. Il Monte Capanne un'isola verde nell'Elba. RS editore, Genova, 51-77.

Fanelli G, Tescarollo P (2005) La vegetazione echinofitica a Genista desoleana del Massiccio del Monte Capanne (Isola d'Elba, Toscana, Italia). Parlatorea 7: 39-46.

Ferretti G, Foggi B (2013) Segnalazioni 245-246. In: Peruzzi L, Viciani D, Bedini G (Eds) Contributi per una flora vascolare di Toscana. IV (181-246) Atti della Società Toscana di Scienze Naturali, Memorie, Serie B 119(2012): 23-32. https://doi.org/10.4081/nhs.2013.115

Ferretti G, Lazzaro L, Giuliani C, Foggi B (2013) Secondo contributo alla conoscenza della flora esotica dell'Arcipelago Toscano, Italia. Atti della Società Italiana di Scienze Naturali, Museo Civico di Storia Naturale di Milano 154(2): 115-130.

Fiori A (1923-1929) Nuova Flora Analitica d'Italia, Vol. 1-2. Tipografia M. Ricci, Firenze.

Fiori A (1943) Flora Italica Cryptogama, Vol. 5. Pteridophyta. Firenze.

Foggi B, Cartei L, Pignotti L, Signorini MA, Viciani D, Dell'Olmo L, Menicagli E (2006) Il paesaggio vegetale dell'Isola d'Elba (Arcipelago Toscano). Studio di fitosociologia e cartografico. Fitosociologia 43(1, Suppl. 1): 3-95. 
Foggi B, Guidi T, Capecchi M, Baldini RM, Grigioni A (2009a) Biological flora of the Tuscan Archipelago islets (Tyrrhenian Sea). Webbia 64(1): 23-45. https://doi.org/10.1080/0083 7792.2009.10670851

Foggi B, Guidi T, Venturi E, Ghisolfi M (2009) Interventi per la conservazione dell'habitat Natura 2000 "Stagni temporanei mediterranei” nell'isola di Capraia (Arcipelago Toscano): primi risultati. Atti della Società Toscana di Scienze Naturali, Memorie, serie B 115(2008): $47-56$.

Foggi B, Venturi E (2010) Segnalazioni 79. In: Peruzzi L, Viciani D, Bedini G (Eds) Contributi per una flora vascolare di Toscana. I. (1-85). Atti della Società Toscana di Scienze Naturali, Memorie, Serie B 116(2009): 33-44.

Foggi B, Viciani D, Baldini RM, Carta A, Guidi T (2015) Conservation assessment of the endemic plants of the Tuscan Archipelago, Italy. Oryx 49(1): 118-126. https://doi. org/10.1017/S0030605313000288

Forbicioni L, Frangini G (2012) Notulae alla checklist della flora vascolare italiana, 14: 1932. Informatore Botanico Italiano 44(2): 392.

Forbicioni L, Frangini G, Pierini B, Ferretti G, Foggi B, Giuliani C, Lazzaro L (2014) Segnalazione 261. In: Peruzzi L, Viciani D, Bedini G (Eds) Contributi per una flora vascolare di Toscana. V (247-319). Atti della Società Toscana di Scienze Naturali, Memorie, Serie B 120(2013): 35-44.

Fossi Innamorati T (1983) La flora vascolare dell'Isola d'Elba (Arcipelago Toscano). Prima parte. Webbia 36(2): 273-411. https://doi.org/10.1080/00837792.1983.10670255

Fossi Innamorati T (1989) La flora vascolare dell'Isola d'Elba (Arcipelago Toscano). Parte seconda. Webbia 43(2): 201-267. https://doi.org/10.1080/00837792.1989.10670454

Fossi Innamorati T (1991) La flora vascolare dell'Isola d'Elba (Arcipelago Toscano). Parte terza. Webbia 45(1): 137-185. https://doi.org/10.1080/00837792.1991.10670494

Fossi Innamorati T (1994) La flora vascolare dell'Isola d'Elba (Arcipelago Toscano). Parte quarta. Webbia 49(1): 93-123. https://doi.org/10.1080/00837792.1994.10670574

Fossi Innamorati T (1997) Addenda ed emendanda alla flora vascolare dell'Isola d'Elba (Arcipelago Toscano). Webbia 51(2): 385-389. https://doi.org/10.1080/00837792.1997.10670625

Frangini G (2004) Gennaria diphylla (Link) Parl., primo ritrovamento in Toscana (Isola d'Elba). GIROS Notizie 27: 28-29.

Frangini G, Carta A (2011) Segnalazione 103. In: Peruzzi L, Viciani D, Bedini G (Eds) Contributi per una flora vascolare di Toscana. II (86-142). Atti della Società Toscana di Scienze Naturali, Memorie, Serie B 117(2010): 23-31.

Frangini G, Carta A (2012) Segnalazione 171. In: Peruzzi L, Viciani D, Bedini G (Eds) Contributi per una flora vascolare di Toscana. III (143-180). Atti della Società Toscana di Scienze Naturali, Memorie, Serie B 118(2011): 39-46.

Frangini G, Carta A, Galasso E (2010) Notulae alla flora esotica d'Italia, 3: 42. Informatore Botanico Italiano 42(2): 533.

Frangini G, Romolini R, Sodi F, Bisti M, Filippi L, Mannocci M, Quochi B (2006) Orchidee dell'Isola d'Elba (Arcipelago Toscano). Nota aggiuntiva. GIROS Notizie 33: 7-15.

Frangini G, Romolini R, Sodi F, Bisti M, Mannocci M, Quochi B (2005) Orchidee dell'Isola d'Elba (Arcipelago Toscano). GIROS Notizie 28: 1-16. 
Frignani F, Iiriti G (2011) The genus Romulea in Italy: taxonomy, ecology and intraspecific variation in relation to the flora of Western Mediterranean islands. Fitosociologia 48(2): $13-20$.

Galasso G, Conti F, Peruzzi L, Ardenghi NMG, Banfi E, Celesti-Grapow L, Albano A, Alessandrini A, Bacchetta G, Ballelli S, Bandini Mazzanti M, Barberis G, Bernardo L, Blasi C, Bouvet D, Bovio M, Cecchi L, Del Guacchio E, Di Pietro R, Domina G, Fascetti S, Gallo L, Gubellini L, Guiggi A, Iamonico D, Iberite M, Jiménez-Mejías P, Lattanzi E, Marchetti D, Martinetto E, Masin RR, Medagli P, Passalacqua NG, Peccenini S, Pennesi R, Pierini B, Podda L, Poldini L, Prosser F, Raimondo FM, Roma-Marzio F, Rosati L, Santangelo A, Scoppola A, Scortegagna S, Selvaggi A, Selvi F, Soldano A, Stinca A, Wagensommer RP, Wilhalm T, Bartolucci F (2018) An updated checklist of the vascular flora alien to Italy. Plant Biosystems 152(3): 556-592. https://doi.org/10.1080/11263504.2018.1441197

Galasso G, Domina G, Bonari G, Buono S, Chianese G, Cortesi G, Frangini G, Iamonico D, Olivieri N, Peruzzi L, Pierini B, Roma-Marzio F, Scoppola A, Soldano A, Stinca A, Tomaselli V, Veronico G, Nepi C (2017) Notulae to the Italian alien vascular flora: 4. Italian Botanist 4: 33-41. https://doi.org/10.3897/italianbotanist.4.21666

Galasso G, Gestri G, Peruzzi L, Banfi E (2011) Notulae alla flora esotica d'Italia, 4: 69. Informatore Botanico Italiano 43(1): 147.

Gatteschi P, Arretini C (1990) I rimboschimenti dell'Arcipelago Toscano: storia, realtà e prospettive. Annali dell'Accademia Italiana di Scienze Forestali 39(1989): 33-54.

Gonnelli V, Carta A, Zoccola A, Landi M, Viciani D, Ferretti G, Quilghini G, Parri F, Giombini R, Marsiaj G (2012) Segnalazione 179. In: Peruzzi L, Viciani D, Bedini G (Eds) Contributi per una flora vascolare di Toscana. III (143-180). Atti della Società Toscana di Scienze Naturali, Memorie, Serie B 118(2011): 39-46.

Greuter W (1995) Origin and peculiarities of Mediterranean island floras. Ecologia Mediterranea 21(1/2): 1-10.

Group of European Pteridologists (2004) GEP NEWS 12: 1-8.

Guiggi A (2008) Catalogo delle Cactaceae naturalizzate in Italia con osservazioni tassonomiche, nomenclaturali e corologiche. Rivista Piemontese di Storia Naturale 29: 103-140.

Guiggi A (2014) Repertorium Cactorum Italicum. Cactology 4: 1-20.

Heywood VH (2017) Plant conservation in the Anthropocene - challenges and future prospects. Plant Diversity 39(6): 314-330. https://doi.org/10.1016/j.pld.2017.10.004

Hofmann A, Goretti D, Tabacchi G, Vignoli M, Bernetti G (1998) L'inventario forestale. Boschi e macchie di Toscana. Firenze, Regione Toscana, 1-219.

Hoffmann V, Hoffmann W (2008) Auf Orchideensuche im Naturpark Toskanischer Archipel, Insel Elba (Italien). Journal of Europäischer Orchideen 40(1): 109-152.

Iamonico D (2015) Taxonomic revision of the genus Amaranthus (Amaranthaceae) in Italy. Phytotaxa 199(1): 1-84. https://doi.org/10.11646/phytotaxa.199.1.1

Iamonico D, Forbicioni L (2011) Segnalazione 91. In: Peruzzi L, Viciani D, Bedini G (Eds) Contributi per una flora vascolare di Toscana. II (86-142). Atti della Società Toscana di Scienze Naturali, Memorie, Serie B 117(2010): 23-31.

Iamonico D, Forbicioni L, Frangini G (2008) Notulae alla checklist della flora vascolare italiana, 6: 1505. Informatore Botanico Italiano 40(2): 259. 
Iamonico D, Forbicioni L, Frangini G (2011) A new hybrid in the genus Ophrys L. (Orchidaceae) from Elba Island (Central Italy). Annales Botanici Fennici 48(6): 435-438. https:// doi.org/10.5735/085.048.0508

Jalas J, Suominen J (Eds) (1976) Atlas Florae Europaeae. Salicaceae to Balanophoraceae. Helsinki, $128 \mathrm{pp}$.

Koestlin CH (1780) Lettres sur l'histoire naturelle de l'Isle d'Elbe écrites a son excellence Monsieur le Comte de Borch. Chez Jean Paul Kraus, Vienne.

Landi S (1989) Flora e ambiente dell'isola d'Elba. Ed. Azzurra, Cavalese, Trento.

Langeneck J, Peruzzi L (2013) Segnalazione 192. In: Peruzzi L, Viciani D, Bedini G (Eds) Contributi per una flora vascolare di Toscana. IV (181-246). Atti della Società Toscana di Scienze Naturali, Memorie, Serie B 119(2012): 23-32.

Lazzaro L, Ferretti G, Galasso G, Lastrucci L, Foggi B (2013a) Contributo alla conoscenza della flora esotica dell'Arcipelago Toscano, Italia. Atti della Società Italiana di Scienze Naturali, Museo Civico di Storia Naturale di Milano 154(1): 3-24.

Lazzaro L, Ferretti G, Giuliani C, Foggi B (2014a) A checklist of the alien flora of the Tuscan Archipelago (Italy). Webbia 69(1): 157-176. https://doi.org/10.1080/00837792.2014.907981

Lazzaro L, Giuliani C, Ferretti G, Guiggi A (2013b) Notulae alla flora esotica d'Italia, 9: 200. Informatore Botanico Italiano 45(2): 310.

Lazzaro L, Mariotti D, Viciani D, Benesperi R, Ferretti G (2014b) Segnalazione 318. In: Peruzzi L, Viciani D, Bedini G (Eds) Contributi per una flora vascolare di Toscana. V (247319). Atti della Società Toscana di Scienze Naturali, Memorie Serie B, 120(2013): 35-44.

Legendre P (2014) Interpreting the replacement and richness difference components of beta diversity. Global Ecology and Biogeography 23(11): 1324-1334. https://doi.org/10.1111/ geb. 12207

Luque SS (2000) The challenge to manage the biological integrity of nature reserves: a landscape ecology perspective. International Journal of Remote Sensing 2: 2613-2643. https:// doi.org/10.1080/01431160050110205

MacArthur RH, Wilson EO (1967) The Theory of Island Biogeography. Princeton University Press.

Mannocci M (2004) Segnalazioni Floristiche Italiane: 1105-1107. Informatore Botanico Italiano 36(1): 81.

Mannocci M (2009) Notulae alla checklist della Flora vascolare Italiana, 8: 1613-1616. Informatore Botanico Italiano 41(2): 356.

Marcello A (1951) Rilevamenti fitofenologici all'Isola d'Elba (Aprile 1950). Nuovo Giornale Botanico Italiano, nuova serie 58: 73-96. https://doi.org/10.1080/11263505109430799

Martini G, Viciani D (2018) What happened to Linnaeus's Iris florentina? Re-evaluation of this taxon at species level. Taxon 63(2): 395-400. https://doi.org/10.12705/672.8

Myers N, Mittermeier RA, da Fonseca GAB, Kent J (2000) Biodiversity hotspots for conservation priorities. Nature 403: 853-858. https://doi.org/10.1038/35002501

Nardi E (1984) The genus Aristolochia L. (Aristolochiaceae) in Italy. Webbia 38: 221-300. https://doi.org/10.1080/00837792.1984.10670308

Natali A (1998) Le groupe Galium lucidum (Rubiaceae) dans le domaine cyrno-sarde. Candollea 53(2): 484-488. 
Negri G (1950) Escursione della Società Botanica all'Isola d'Elba (aprile 1950). Appunti sulla vegetazione. Nuovo Giornale Botanico Italiano, nuova serie 57: 276-293.

Nunn PD (2004) Through a mist on the ocean: human understanding of island environments. Tijdschrift voor Economische en Sociale Geografie 95(3): 311-325. https://doi. org/10.1111/j.1467-9663.2004.00310.x

Ottens C (1967) Über Orchideenvorkommen auf der Insel Elba. Die Orchidee 18(2): 63-66. Paoli P, Romagnoli G (1976) La flora vascolare dell'isola di Montecristo (Arcipelago Toscano). Webbia 30(2): 303-456. https://doi.org/10.1080/00837792.1976.10670055

Peruzzi L (2018) Floristic inventories and collaborative approaches: a new era for checklists and floras? Plant Biosystems 152(2): 177-178. https://doi.org/10.1080/11263504.2017.1419997

Peruzzi L, Bedini G (Eds) (2015 onwards) Wikiplantbase \#Toscana v. 2.1. http://bot.biologia. unipi.it/wpb/toscana/index.html [accessed 1 March 2018]

Peruzzi L, Carta A (2011) Crocus ilvensis sp. nov. (sect. Crocus, Iridaceae), endemic to Elba Island (Tuscan Archipelago, Italy). Nordic Journal of Botany 29(1): 6-13. https://doi. org/10.1111/j.1756-1051.2010.01023.x

Peruzzi L, Carta A (2013) A taxonomic revision of Silene nocturna species complex (Caryophyllaceae) in Italy. Phytotaxa 88(3): 38-48. https://doi.org/10.11646/phytotaxa.88.3.1

Peruzzi L, Carta A, Gestri G, Pierini B (2009) Aggiornamenti e novità sulla distribuzione del genere Gagea (Liliaceae) in Toscana. Atti della Società Toscana di Scienze Naturali, Memorie, Serie B 115(2008): 95-98.

Peruzzi L, Conti F, Bartolucci F (2014) An inventory of vascular plants endemic to Italy. Phytotaxa 168(1): 1-75. https://doi.org/10.11646/phytotaxa.168.1.1

Peruzzi L, Domina G, Bartolucci F, Galasso G, Peccenini S, Raimondo FM, Albano A, Alessandrini A, Banfi E, Barberis G, Bernardo L, Bovio M, Brullo S, Brundu G, Brunu A, Camarda I, Carta L, Conti F, Croce A, Iamonico D, Iberite M, Iiriti G, Longo D, Marsili S, Medagli P, Pistarino A, Salmeri C, Santangelo A, Scassellati E, Selvi F, Soldano A, Stinca A, Villani M, Wagensommer RP, Passalacqua NG (2015) An inventory of the names of vascular plants endemic to Italy, their loci classici and types. Phytotaxa 196(1): 1-217. https://doi.org/10.11646/phytotaxa.196.1.1

Peruzzi L, Jarvis CE, Carta A (2014) On the application of the Linnaean names Cucubalus reflexus, Silene nocturna and Silene mutabilis (Caryophyllaceae).Taxon 63(3): 651-652. https://doi.org/10.12705/633.6

Peruzzi L, Pierini B, Gestri G (2013) Notulae alla flora esotica d'Italia, 9: 185. Informatore Botanico Italiano 45(2): 308.

Peruzzi L, Viciani D, Angiolini S, Astuti G, Banfi E, Benocci A, Bonari G, Bruni G, Caramante P, Caré M, Carta A, Castagnini P, Cheli A, Ciampolini F, D’Antraccoli M, Ferretti G, Ferruzzi S, Fiaschi T, Foggi B, Fontana D, Galasso G, Gallo L, Galvani D, Gestri G, Grazzini A, Lastrucci L, Lazzaro L, Loppi S, Manganelli G, Mugnai M, Piazzini S, Pierini B, Roma-Marzio F, Sani A, Selvi F, Soldano A, Stinca A, Bedini G (2017) Contributi per una flora vascolare di Toscana. IX (507-605). Atti della Società Toscana di Scienze Naturali, Memorie, Serie B 124: 73-86.

Pierini B (2014) Segnalazioni 262-264. In: Peruzzi L, Viciani D, Bedini G (Eds) Contributi per una flora vascolare di Toscana. V (247-319). Atti della Società Toscana di Scienze Naturali, Memorie, Serie B 120(2013): 35-44. 
Pierini B, Peruzzi L (2012) Notulae alla flora esotica d'Italia, 6: 136. Informatore Botanico Italiano 44(2): 399.

Pignatti S (1982a) Flora d'Italia, Vol. 1-3. Edagricole, Bologna.

Pignatti S (1982b) New species of Limonium from Italy and Tunesia. Webbia 36(1): 47-56. https://doi.org/10.1080/00837792.1982.10670239

Pignotti L (2003) Scirpus L. and related genera (Cyperaceae) in Italy. Webbia 58(2): 281-400. https://doi.org/10.1080/00837792.2003.10670754

R Development Core Team (2017) The R Foundation for Statistical Computing. version 3.4.3. Rinaldi G (2000) Flora dell'Arcipelago Toscano. Ed. Archipelagos, Portoferraio, Livorno.

Rizzotto M (1999) Research on the genus Limonium (Plumbaginaceae) in the Tuscan Archipelago (Italy). Webbia 53(2): 241-282. https://doi.org/10.1080/00837792.1999.10670663

Roma-Marzio F, Bedini G, Müller, Peruzzi L (2016) A critical checklist of the woody flora of Tuscany. Phytotaxa 287(1): 1-135. https://doi.org/10.11646/phytotaxa.287.1.1

Roma-Marzio F, Najar B, Alessandri J, Pistelli L, Peruzzi L (2017) Taxonomy of prickly juniper (Juniperus oxycedrus group): a phytochemical-morphometric combined approach at the contact zone of two cryptospecies. Phytochemistry 141: 48-60. https://doi.org/10.1016/j. phytochem.2017.05.008

Scoppola A, Lattanzi E, Bernardo L (2016) Distribution and taxonomy of the Italian clovers belonging to Trifolium sect. Vesicastrum subsect. Mystillus (Fabaceae). Italian Botanist 2: 7-27. https://doi.org/10.3897/italianbotanist.2.10361

Signorini MA, Foggi B (1998) A survey of the genus Festuca L. (Poaceae) in Italy. Festuca gamisansii Kerguélen subsp. aethaliae, subsp. nova. Plant Biosystems 132(2): 105-112. https:// doi.org/10.1080/11263504.1998.10654197

Signorini MA, Foggi B, Baldini R (Eds) (2002) Escursione all'Arcipelago Toscano. Atti e Resoconti Sociali. Informatore Botanico Italiano 34(1): 232-234.

Signorini MA, Tani C (2015) Numeri Cromosomici per la Flora Italiana: 1499. Informatore Botanico Italiano 47(1): 61-62.

Sommier S (1902) La flora dell'Arcipelago Toscano. Nuovo Giornale Botanico Italiano, nuova serie 9(2): 319-354.

Sommier S (1903) La flora dell'Arcipelago Toscano. Nota II. Nuovo Giornale Botanico Italiano, nuova serie 10(2): 133-200.

Tavormina G (2006) Succulente della flora italiana. Le specie esotiche naturalizzate in Italia. Piante Grasse 26(4): 140-150.

Thiébaut De Berneaud A (1808) Voyage a l'Isle d'Elbe, suivi d'une notice sur les autres isles de la Mer Tyrrhénienne. Colas, Paris.

Thomson SA, Pyle RL, Ahyong ST, Alonso-Zarazaga M, Ammirati J, Araya JF, Ascher JS, Audisio TL Azevedo-Santos VM, Bailly N, Baker WJ, Balke M, Barclay MVL, Barrett RL, Benine RC, Bickerstaff JRM, Bouchard P, Bour R, Bourgoin T, Boyko CB, Breure ASH, Brothers DJ, Byng JW, Campbell D, Ceríaco LMP, Cernák I, Cerretti P, Chang CH, Cho S, Copus JM, Costello MJ, Cseh A, Csuzdi C, Culham A, D’Elía G, d'Udekem d'Acoz C, Daneliya ME Dekker R, Dickinson EC, Dickinson TA, van Dijk PP, Dijkstra KB, Dima B, Dmitriev DA, Duistermaat L, Dumbacher JP, Eiserhardt WL, Ekrem T, Evenhuis NL, Faille A, Fernández-Triana JL, Fiesler E, Fishbein M, Fordham BG, Freitas AVL, Friol NR, 
Fritz U, Frøslev T, Funk VA, Gaimari SD, Garbino GST, Garraffoni ARS, Geml J, Gill AC, Gray A, Grazziotin FG, Greenslade P, Gutiérrez EE, Harvey MS, Hazevoet CJ, He K, He X, Helfer S, Helgen KM, Heteren AH van, Hita Garcia F, Holstein N, Horváth MK, Hovenkamp PH, Hwang WS, Hyvönen J, Islam MB, Iverson JB, Ivie MA, Jaafar Z, Jackson MD, Jayat JP, Johnson NF, Kaiser H, Klitgård BB, Knapp DG, Kojima JI, Kóljalg U, Kontschán J, Krell FT, Krisai-Greilhuber I, Kullander S, Latella L, Lattke JE, Lencioni V, Lewis GP, Lhano MG, Lujan NK, Luksenburg JA, Mariaux J, Marinho-Filho J, Marshall CJ, Mate JF, McDonough MM, Michel E, Miranda VFO, Mitroiu MD, Molinari J, Monks S, Moore AJ, Moratelli R, Murányi D, Nakano T, Nikolaeva S, Noyes J, Ohl M, Oleas NH, Orrell T, Páll-Gergely B, Pape T, Papp V, Parenti LR, Patterson D, Pavlinov IY, Pine RH, Poczai P, Prado J, Prathapan D, Rabeler RK, Randall JE, Rheindt FE, Rhodin AGJ, Rodríguez SM, Rogers DC, Roque FO, Rowe KC, Ruedas LA, Salazar-Bravo J, Salvador RB, Sangster G, Sarmiento CE, Schigel DS, Schmidt S, Schueler FW, Segers H, Snow N, Souza-Dias PGB, Stals R, Stenroos S, Stone RD, Sturm CF, Štys P, Teta P, Thomas DC, Timm RM, Tindall BJ, Todd JA, Triebel D, Valdecasas AG, Vizzini A, Vorontsova MS, de Vos JM, Wagner P, Watling L, Weakley A, Welter-Schultes F, Whitmore D, Wilding N, Will K, Williams J, Wilson K, Winston JE, Wüster W, Yanega D, Yeates DK, Zaher H, Zhang G, Zhang ZQ, Zhou HZ (2018) Taxonomy based on science is necessary for global conservation. PLoS Biology 16(3): e2005075. https://doi.org/10.1371/journal.pbio.2005075

Troia A, Santangelo A, Gianguzzi L (2018) Nomenclatural remarks on Carex sect. Sylvaticae (Cyperaceae): C. laxula and related names. Phytotaxa 349(1): 79-84. https://doi. org/10.11646/phytotaxa.349.1.10

Vagge I, Biondi E (1999) La vegetazione delle coste sabbiose del Tirreno settentrionale italiano. Fitosociologia 36(2): 61-95.

Viegi L, Cela Renzoni G (1981) Flora esotica d'Italia: le specie presenti in Toscana. C.N.R., Coll. Progr. Final. "Promozione della Qualità dell'ambiente", AQ/1/132, Roma.

Vogiatzakis IN, Pungetti G, Mannion AM (2008) Mediterranean island landscapes: natural and cultural approaches. Springer Science \& Business Media. https://doi.org/10.11646/ phytotaxa.349.1.10

Whittaker RJ, Fernandez-Palacios JM (2013) Island Biogeography. Ecology, Evolution and Conservation. Oxford University Press, Oxford.

Zangheri P (1976) Flora Italica, Vol. 1-2. Cedam, Padova. 


\section{Supplementary material I}

\section{Supplementary data}

Authors: Angelino Carta, Leonardo Forbicioni, Giuliano Frangini, Brunello Pierini, Lorenzo Peruzzi

Data type: specimens data

Explanation note: 1. Floristic list and records. 2. Toponyms arranged by Operational Geographic Unit.

Copyright notice: This dataset is made available under the Open Database License (http://opendatacommons.org/licenses/odbl/1.0/). The Open Database License $(\mathrm{ODbL})$ is a license agreement intended to allow users to freely share, modify, and use this Dataset while maintaining this same freedom for others, provided that the original source and author(s) are credited.

Link: https://doi.org/10.3897/italianbotanist.6.26568.suppl1 